\title{
Interventions to Increase Moderate-to-Vigorous Physical Activity in Elementary School Physical Education Lessons: Systematic Review
}

Lan Sum Wong, MEda Ann-Marie Gibson, PhDb Abdulaziz Farooq, MSc MPHc John Joseph Reilly, PhDd aDoctoral Student, (lan.wong@strath.ac.uk), University of Strathclyde, Graham Hills Building, 50 George Street, Glasgow G1 1QE, UK.

bSenior Lecturer, (annmarie.gibson2015@gmail.com) University of Strathclyde, Graham Hills Building, 50 George Street, Glasgow G1 1QE, UK.

cEpidemiologist, (mohammed.farooq@aspetar.com) Research and Scientific Support Department, Aspetar Orthopaedic and Sports Medicine Hospital, P. O. Box 29222 Doha, Qatar.

dProfessor, (john.j.reilly@strath.ac.uk) University of Strathclyde, Graham Hills Building, 50 George Street, Glasgow G1 1QE, UK. 


\section{ABSTRACT}

BACKGROUND: This systematic review aimed to synthesise recent evidence on interventions to increase Moderate-to-Vigorous Physical Activity (MVPA) content of Physical Education (PE) in children age 8 to 11 .

METHODS: A search of 6 databases was conducted in December 2019. Controlled intervention studies were included so long as they used objective measures of MVPA. Methodological quality was assessed using the appropriate Joanna Briggs Institute (JBI) Checklist. Random effects meta-analysis was used where appropriate.

RESULTS: Of the 5459 records, only five studies met all inclusion criteria, reporting on 1452 participants; three Quasi-Experimental studies and two RCTs. All five eligible studies reported favorable intervention effects. Meta-analysis was possible from 4/5 studies: the mean difference between intervention and control groups at follow-up was $+14.3 \%$ of lesson time in MVPA (CI 2.7 to 25.8).

CONCLUSIONS: Efforts to increase the MVPA content of elementary school PE are achievable. Two studies employed PE specialist teachers and one study used an expert instructor as their intervention, two studies worked with the class teachers using selfdetermination theory. All studies focused on health (MVPA) outcomes and included either 'fitness infusions' or physically active games to engage students' in physical activities and increase their activity level. 
Regular moderate-to-vigorous physical activity (MVPA) provides a range of benefits for children and young people: physical and mental health ${ }^{1}$ and non-health benefits such as cognitive development and educational attainment. ${ }^{2,3}$ Low MVPA among children and young people, plus the growth of sedentary time via social media and advent of more digital platforms and mobile devices is being regarded as the next major global public health issue. ${ }^{4,5}$ A more active lifestyle in childhood is crucial in improving short-term health and wellbeing, as well as reducing risk of many Non-Communicable Diseases (NCD) in later life. ${ }^{6,7}$

According to Metzler et al. ${ }^{8}$ Physical Education (PE) is the only place where children have an opportunity to engage in MVPA, become physically fit, and learn the movement and behavioral skills needed for a lifetime of active, healthy living. Furthermore, all school-age children spend around half of their days per year at school, making the school environment a strategically important setting for the promotion of MVPA. ${ }^{9}$ For example, the United States Centres for Disease Control and Prevention (CDC, USA) ${ }^{10}$ and the UK Association for Physical Education (PE) (AfPE, UK) ${ }^{11}$ recommend that MVPA levels during elementary school PE lessons should reach $50 \%$ of lesson time, a meaningful contribution to the 60 minutes minimum MVPA per day recommended. ${ }^{12}$ These also align with "health optimizing physical education" (HOPE), the concept that PE should make an important contribution to health-related physical activity and fitness, all students are engaged and active at least $50 \%$ of the PE lesson time. ${ }^{9}$ Furthermore, PE participation is one of the entry points for students' lifelong participation in MVPA, sports and society at large. ${ }^{13-16}$

Despite the potential of school PE for increasing MVPA and improving public health, a systematic review carried out by Hollis et al. ${ }^{17}$ in 2015 showed MVPA levels during elementary school PE lessons typically do not meet the recommendation of $50 \%$ of lesson time. Their findings suggested that interventions to increase the proportion of PE lesson time spent in MVPA were needed. The systematic review of PE interventions aimed at increasing MVPA by 
Lonsdale et al. ${ }^{18}$ in 2013 was comprehensive, but the most recent eligible study included in that review is now over a decade old (published in 2008). Moreover, the Lonsdale et al. review was wide-ranging, including both children and adolescents, and identified 14 eligible studies, most (10/14) from the USA, with potentially limited generalizability beyond the USA. Lonsdale et al. ${ }^{18}$ found that many of the eligible studies were quite limited (small sample sizes were common) and the evidence should be considered with caution. Overall, they concluded that PE-based interventions could increase MVPA content of PE lessons by up to about 24\% compared with usual practice. ${ }^{18}$ They also concluded that professional learning focused on PE teacher pedagogy offered considerable potential for increasing physical activity (PA) in children and youth, but higher quality trials were needed to determine how best to promote MVPA in PE lessons, and to determine the most effective and sustainable intervention strategies. Since the review by Lonsdale et al. included evidence across elementary ( 7 out of 14 eligible studies), middle, and high schools, their eligible evidence was largely from the USA, from studies published over a decade ago, and from a somewhat limited evidence base, there was a need for a new review to examine whether the evidence base had improved in recent years.

Across the western world there is now clear evidence that MVPA levels of children are low and in decline before adolescence. ${ }^{19}$ Interventions are therefore required pre-adolescence to increase MVPA levels and mitigate this age-related decline. ${ }^{20}$ Interventions are therefore required for elementary school children. ${ }^{19,20}$ In the UK, the Medical Research Council Framework on the Development and Evaluation of Complex Interventions ${ }^{21}$ recommends that thorough searching of intervention evidence is used to inform intervention development. The present review was intended as the foundation of school PE-based intervention development aimed at increasing MVPA in children (8.0 to 11.9 years) in Scotland, and was intended to identify new/existing interventions which might be adapted for use in Scotland. Our intervention development is focused on 8.0-11.9 year olds and therefore the review focused on 
intervention strategies for that age group: intervention evidence from younger children and older youth would probably be less generalizable, and so were beyond the scope of the present review.

The primary aim of this study was to systematically review the more recent global evidence, published after Lonsdale's review (which had only 7 eligible older studies in our target age range, 4 from the USA), to identify promising ways to increase MVPA in elementary school PE lessons for children in the upper stages of primary school education in Scotland (age 8.0-11.9 years).

\section{METHODS}

\section{Literature Search}

This study followed the PRISMA statement for conducting and reporting systematic reviews and meta-analyses. The protocol was registered on PROSPERO on the $11^{\text {th }}$ November 2019. (http://www.crd.york.ac.uk/PROSPERO/display_record.php?ID=CRD42019155878).

Up to December 2019, eligible studies were identified in six relevant electronic databases, Scopus, SPORTDiscus, PsycINFO, ProQuest, PubMed and ERIC. The search strategy followed the PICOS (population, intervention, comparison, outcomes, and study design) framework. The inclusion and exclusion criteria are detailed below. The search was limited to 2010-2019 (aimed updating the previous review by Lonsdale et al., 2013), it was also restricted to search for English language studies only due to the impracticalities of translating papers. An example of a search strategy for the Scopus database is provided in Table 1, which was adapted for the five other databases. Hollis's ${ }^{17}$ and Lonsdale's ${ }^{18}$ citation lists, as well as reference lists of the final included papers, were examined to find any potential eligible studies missed during the database search.

References were imported into Endnote and duplicates were removed, at which point one author screened the titles and abstracts with 81 full-text articles were identified. Three authors then screened potentially relevant full-text articles independently based on the inclusion and 
exclusion criteria. Any disagreement was resolved through discussions among the three authors.

\section{Inclusions/Exclusion Criteria}

Population. Studies of apparently healthy elementary school children aged 8.0 to 11.9 years old were included in the present systematic review, with studies excluded if the mean age of study participants was $<8.0$ or $>11.9$ years. The reasons of selecting this age range were partly scientific: late childhood/early adolescence $=$ mid-late elementary years represents a fairly homogenous group likely to experience sharply declining MVPA, and partly pragmatic: this review was undertaken in order to help inform development of a PE intervention for 8-11 years old in Scotland as noted above. Studies of children with any intellectual, physical or cognitive disabilities, which may impair their ability to engage in PA, were excluded.

Intervention. For inclusion in the present review, the interventions had to take place in PE lessons. If the intervention was multi-component, MVPA had to be described as the predominant component in the publication. Interventions which addressed other domains of PA (pre or after school, recess), or which were set in the community or home were excluded. Comparison. For inclusion in the review, the interventions had to be compared to a comparison or control group, who received either no treatment, another PA intervention, other lifestyle intervention, waitlist control or attentional control. Uncontrolled studies were excluded.

Outcomes. For inclusion, the studies must have had MVPA outcomes measured using an objective method (using an accelerometer or direct observation method). PA outcomes measured using self-report, or questionnaire, or an objective measurement that did not give an intensity (pedometers), or studies that measured a small period of the day other than PE (such as recess interventions) were excluded. 
Study design. Studies included in the systematic review had to have intervention and control groups, either quasi-experimental designs (non-randomized experimental studies) or randomized controlled trials (RCT) or cluster randomized controlled trials.

\section{Data Extraction}

Data were extracted by one of the authors and checked by a second. In cases where data were missing, or additional information was required for the eligible studies, the study authors were contacted to provide the relevant information. Authors of two of the potentially eligible studies were contacted to determine if the study interventions and designs met the inclusion criteria. One for additional information on the mean (SD) or median (age) of study participants at baseline; the other to clarify the size of the intervention effect in the paper. As one of the authors was unable to provide the details, this paper was not included in the present review. ${ }^{22}$

\section{Data Analysis and Synthesis}

A narrative synthesis was conducted on outcomes for each included paper. The outcome of interest was MVPA during PE, and meta-analysis was possible for 4 of the 5 eligible studies, on the mean difference in the MVPA content of PE lesson time at follow-up between intervention vs control groups. Two of the four studies did not provide the standard deviation (SD) for MVPA content of PE, but instead median and inter-quartile range was provided. In these two cases median values were assumed as mean values and SD was estimated using methods described in Wan et al. ${ }^{23}$ A random effect meta-analysis was performed for the mean difference and the standardized mean difference with $95 \%$ confidence intervals (CI). Heterogeneity across studies was assessed using $\mathrm{I}^{2}$ statistics ( $\mathrm{I}^{2}$ of $0-40 \%$ represents low heterogeneity and $75-100 \%$ considerable heterogeneity). ${ }^{24}$ All statistical analyses were performed using metafor package (in RStudio, Version 1.2.5001).

\section{Quality Assessment}

Two authors independently assessed the quality of the eligible papers using the quality assessment tool of the JBI Critical Appraisal Checklist for Quasi-Experimental Studies (non- 
randomized experimental studies) $)^{25}$ and JBI Critical Appraisal Checklist for Randomized Controlled Trials (RCT), ${ }^{26}$ referring to a third author when required. The Checklists were used to assess the methodological quality and to determine the extent to which a study addressed the possibility of bias in its design, conduct, analysis, and reporting.

\section{RESULTS}

\section{Identification and Selection of the Studies}

The PRISMA flow diagram ${ }^{27}$ is presented in Figure 1. From an initial pool of 5459 records (identified from six databases and 100 records through other sources), 5200 remained once duplicates were removed. Following the title and abstract review, 81 full-text papers were retrieved and reviewed for eligibility. Five papers met all the inclusion criteria (Boulley et al., 2018; Fairclough et al., 2016; Powell et al., 2016; Smith et al., 2015 and Telford et al., 2016) ${ }^{28-}$ ${ }^{32}$ and no further papers were identified when searching references of the five included studies. All study selection discrepancies between the three authors were resolved through discussion.

\section{Characteristics of the Eligible Studies}

An overview of the included studies is presented in Table 2. Three studies were conducted in the UK (Fairclough et al., 2016, Powell et al., 2016 and Smith et al., 2015), one in France (Boulley et al., 2018) and one in Australia (Telford et al., 2016). The eligible studies had a total of 1452 participants (in both intervention and control groups). The duration of the interventions varied from 6 weeks to 4 years, involving elementary children with mean age 9.8 years. Of the five included studies, three of them were quasi-experimental studies (nonrandomized experimental studies) and two were RCTs.

A range of PE interventions were utilised in the five included studies-a common feature was either to use specialist PE teachers, an expert instructor or class teachers (provided with relevant program training) to conduct the interventions. Three studies, Boulley et al., ${ }^{28}$ Powell et al. ${ }^{30}$ and Smith et al. ${ }^{31}$ (with mean age 9.3 years) focused on theory-based teaching strategy interventions which supported generalist (class teachers, not PE specialists) teachers ${ }^{28,30}$ or PE 
specialists $^{31}$ in increasing children's MVPA during school PE lessons. Boulley et al. ${ }^{28}$ aimed to test the effects of a self-determination theory-based teacher professional development program, on elementary teachers' need-supportive motivating style and their students' physical activity (PA) in PE lessons. Class teachers in the intervention group received 12 hours professional development training (separated into four 3-hour workshops over one school year). Students' PA and teachers' motivating style were assessed via accelerometers and direct observation. Results showed that, compared to class teachers in the control group, teachers who attended the professional development training improved their need-supportive motivating style and their students increased their time spent in MVPA. Average percentage of students' PE time in MVPA in the intervention group was 53\% compared with $43 \%$ in the control group at the latest complete follow-up.

Powell's study ${ }^{30}$ aimed at developing teacher effectiveness through the 'SHARP Principles Model' which involved the following key pedagogical aspects: stretching whilst moving; high repetition of motor skills, accessibility through differentiation, reducing sitting and standing and promoting in-class physical activity. The SHARP Principles Model was grounded in theoretical frameworks namely the self-determination theory, the social ecological model and key components (barrier identification, action planning and providing instruction) from behavior change taxonomy. A set of teaching principles was developed to provide class teachers with key elements to focus on in both the planning stage and the delivery of their PE lessons. Workshops and resource cards illustrating the Model were provided to enhance teacher's pedagogy. According to the qualitative findings of this study, the generalist class teachers became conscious of increasing the opportunities for children to learn skills in a more active way. The proportion of time children were engaged in MVPA during PE lessons in the intervention school increased significantly from baseline (mean 43\%) to post-intervention (mean $73 \%$ ). 
Smith et al. ${ }^{31}$ aimed to increase MVPA through two pedagogical models; direct instruction (used in the control group) and the tactical games model (used in the intervention group), also based on self-determination theory but delivered by PE specialists. The findings showed that boys in the intervention group displayed significantly higher levels of MVPA in both rugby (55.7\% SD 3.9) and football (67.8\% SD 7.1) activities in comparison to the control groups' in rugby (41.0\% SD 5.1) and football activities (54.6\% SD 7.3). While girls in the intervention group recorded comparable MVPA levels in the football sessions, they recorded significantly lower MVPA levels in the netball lessons. As regard to the levels of students' self-determined motivation, no significant differences in both boys' and girls' motivation were noted.

Two studies, Telford et al. ${ }^{32}$ and Fairclough et al. ${ }^{29}$ used PE specialist teachers and an expert instructor respectively to try to increase the MVPA content of PE. Telford's 'Lifestyle of our Kids' study ${ }^{32}$ used a specialist-taught PE program. Two intervention lessons per week were conducted by a PE specialist which amounted to 90 min of the mandatory $150 \mathrm{~min}$ per week. The remaining $60 \mathrm{~min}$ of required weekly PE was delivered by class teachers. The intervention, comprising of game play, fitness activities, skill practice and core movement, increased student's MVPA significantly during PE lessons by $6.5 \mathrm{~min}$ on average. This was attributable largely to longer PE lessons and more physically active lessons delivered by the teachers with training in PE compared to generalist class teachers.

Fairclough et al. ${ }^{29}$ was a pilot study and they used the 'Born to Move' fitness intervention movement (including move, punch, kick, jump, dance, core, games and yoga) categories program to promote PA and fitness for children. The 'Born to Move' program was delivered (by an expert instructor) twice a week alongside one regular PE lesson in the intervention schools. While children in the comparison schools received their regular twice-weekly PE as specified in the curriculum and the lessons were delivered by their regular class teachers. Participants, including students and teachers, found that the aims of enjoyment, engagement, inclusivity and challenge were satisfied. Overall this 'Born to Move' program engaged 
children in significantly more 'moderate PA' (MPA) (mean 14 minutes/lesson) than during comparison group PE ( 8 minutes/lesson), and with a median of $51 \%$ of PE lesson time as MVPA in the intervention group vs $32 \%$ in the comparison group.

To summarise, the eligible studies generally found positive effects of their interventions on the content of MVPA during PE. Interventions were quite heterogeneous in intervention duration or follow-up, method of measurement of MVPA, age, one was a pilot study, and 3/5 had a theoretical basis (all three based on self-determination theory). Three used selfdetermination theory to inform interventions and two of them aimed at changing current generalist class teachers' behaviour. Some interventions were less generalizable to the Scottish setting than others, for example the sport-based intervention of Smith et al. would not readily match the Scottish PE curriculum, and both of the Smith's and Telford's interventions depended on specialist PE teachers which are not available universally in Scotland (where primary school PE depends largely on generalist class teachers).

\section{Meta-analysis}

Four of the five eligible studies reported comparable findings, ${ }^{28-30,32}$ i.e. differences in the MVPA content of PE (as a \% of PE lesson time) between intervention and control groups at follow up. These four studies were pooled using random effects meta-analysis, having first estimated the SD in 2/4 studies using metafor package (in RStudio, Version 1.2.5001). Pooled estimates of effect of PE interventions expressed as mean difference between intervention and control on $\%$ time in MVPA during PE was $+14.3 \%(\mathrm{CI}+2.7$ to $+25.8 \%)$ significantly favouring interventions. The $\mathrm{I}^{2}$ statistics of $97.3 \%$ confirmed high level of heterogeneity. Funnel plots were created and Egger tests of asymmetry was performed. Although visual inspection suggested asymmetry, the Egger's test gave a $\mathrm{z}=0.55, \mathrm{p}=0.5817$ confirming symmetry, probably due to the small number of included studies.

\section{Quality Assessment of Eligible Studies}


Quality assessment of the eligible studies is summarized in Table 3 (for quasi-experimental studies) and Table 4 (for the RCTs). Evidence quality was generally high, with the range of items conducted and reported adequately from 7-8/9 for the quasi-experimental studies ${ }^{22}$ and for the cluster RCTs, 9/12 and 7.5/12 items were conducted and reported adequately. ${ }^{23}$ One item found typically weak in study reporting was "statistical analysis" in quasi-experimental studies as there were no mention of power and clustering in most cases.

\section{DISCUSSION}

The present review found favorable intervention effects on children's MVPA in all the studies, with a pooled effect of $14.3 \%$ higher lesson time in MVPA in the intervention groups, equivalent to around a 9 minute improvement in MVPA per one hour of PE lesson time. The range was from a $4 \%$ to $30 \%$ difference in the MVPA content of PE lessons. The present review therefore suggests that interventions to increase the MVPA content of elementary school PE are worthwhile. School should also protect PE time to ensure that the recommended amount of class time for PE is actually made available. ${ }^{32}$ The eligible intervention studies had certain components which may help explain their success in increasing MVPA in PE. Notably, they included: (1) A focus on active learning approaches and health; (2) a theory and evidencebased approach (using the theoretical framework of self-determination theory); (3) an emphasis on fitness and enjoyable activities in the intervention lessons to enhance children's motivation and engagement.

The present review aimed to update Lonsdale et al.'s study of elementary or secondary school PE interventions to increase MVPA in 2013, in which they identified studies published up to 2008. ${ }^{18}$ The five eligible studies in the present review were of high methodological quality, though, as in the Lonsdale systematic review, the evidence was entirely from high-income, western countries. With the problem of low MVPA among students all over the world, more intervention studies are needed in other countries. The information learned from successful 
interventions could have a positive impact on other sociocultural contexts where interests, values and social norms in school and in society are different (such as Singapore, Hong Kong). Previous systematic reviews ${ }^{17,18}$ have found that MVPA levels in school PE were often quite low, and had reported many barriers to higher activity levels in elementary school PE lessons. Among these were policy and infrastructure barriers (such as did no protection for PE time, low teacher confidence in their PE teaching ability, resulting in limited expertise in teaching active lessons and less MVPA than would be desirable). The present review is consistent with Hollis et al. ${ }^{17}$ and Lonsdale et al. ${ }^{18}$ in that PE-based interventions or well-designed PE programs (with enjoyable and fitness-based activities) could have a positive influence on the total amount of MVPA children participate in.

\section{Limitations}

The methodological quality of all eligible papers was generally high which means the risk of bias in individual studies was low. However, a few limitations of this review must also be acknowledged. Our review only included studies in English language which may have limited the number of included studies. Since there were so few studies, and only two were randomized, there may be a need to evaluate the effects of interventions to increase MVPA level in high-quality cluster RCTs in the future. Outcome measurement was objective in all included studies but $3 / 5$ of these studies used SOFIT which tends to overestimate MVPA ${ }^{17}$ so percentage time in MVPA and minutes spent in MVPA during PE lessons in the eligible studies may have been lower than reported.

Publication bias is a concern with intervention studies. A funnel plot was used to test for publication bias in the present study, but this was limited by the small number of eligible studies. While meta-analysis was supportive of benefits to intervention, this conclusion is tentative because the interventions were so heterogeneous - future research is advisable to estimate the magnitude of intervention effects.

\section{Conclusions}


All studies in this review reported a favorable intervention effect upon increasing children's MVPA, suggesting that efforts to increase the MVPA content of elementary school PE are achievable. All studies had a focus on MVPA (health) outcomes and had PE pedagogical objectives to develop teaching effectiveness. Three of the studies used behavioral theory based intervention ( 2 with class teachers and 1 with PE specialists). The remaining two studies used either an expert instructor or specialist PE teachers. It was important to support teachers to teach and students to learn, by providing interventions based on teacher professional development programs/workshops and on theoretical framework of self-determination theory. ${ }^{28,30,31}$ One new/existing intervention from England, ${ }^{33}$ published after the systematic review by Lonsdale et al. was identified as promising and probably generalizable to Scotland, and so potentially useful for our future intervention development in children in upper primary school in Scotland. Since the number of eligible intervention studies in this age group was relatively small and heterogeneous, though of reasonably high-quality, further studies are recommended. Games centred/motivational approaches to enhance children's enjoyment and engagement in PE lessons may be effective ways to increase children's MVPA levels.

\section{IMPLICATIONS FOR SCHOOL HEALTH}

PE can play an important role in promoting students' MVPA level in school, but previous studies have shown that this potential is not being realised because PE lessons are typically not as physically active as they could be and children not as engaged as they could be. The potential of PE to contribute to public health goals by promoting MVPA might be underappreciated by educators and health policymakers, as schools tend to prioritise other aspects of the curriculum such as literacy and numeracy. Achieving the WHO recommendation of at least 60 mins of MVPA daily will improve public health so the objective of school and PE lessons should be to assist children meet the recommendation by making PE more physically active. Doing so should be equitable since all children attend school. As reflected by Eloise et al. ${ }^{34}$ 
"high-quality physical education" helps students build up the skills and knowledge that they have acquired to participate in and enjoy physical activity.

Practical lessons from the present study for class teachers, school principals, as well as education and health policymakers are as follows:

(1) Put more emphasis on the public health goals of PE - more active PE delivers health benefits to school students - helps children build a solid health foundation, reduces the risks from infectious diseases, such as the Covid-19 pandemic, and prevents many NonCommunicable Diseases in later life;

(2) The teachers, either PE trained specialists or generalist class teachers, must plan their PE lessons to have more MVPA content such that all children are engaged;

(3) Chose activities that encourage MVPA behavior - fitness infusion activity, competition, modified games;

(4) Provide training and professional development to modify teaching pedagogy to enhance students' motivations to be active in PE; and

(5) Reduce sedentary time by avoiding children standing around, queuing up, listening to long instructions, or selecting games where only a portion of children are active.

\section{Human Subjects Approval Statement}

As a literature review not involving original research on human subjects, this study did not require review by an institutional review board.

\section{Conflicts of Interests}

The authors declare no conflicts of interest. 


\section{REFERENCES}

1. Janssen I, Leblanc AG. Systematic review of the health benefits of physical activity and fitness in school-aged children and youth. Int J Behav Nutr Phys Act. 2010;7:40.

2. Raspberry CN, Lee SM, Robin L, Laris BA, Russell LA, Coyle KK, et al. The association between school-based physical activity, including physical education, and academic performance: a systematic review of the literature. Prev Med. 2011;52(Suppl 1):S10-S20.

3. Booth JN, Joinson C, Boyle JM, Leary SD, Ness AR, Tomporowski PD, et al. Associations between objectively measured physical activity and academic attainment in adolescents from a UK cohort. Br J Sports Med. 2014;48:265-270.

4. Aubert S, Barnes JD, Abdeta C, Abi Nader P, Adeniyi AF, Aguilar-Farias N, et al. Global matrix 3.0 physical activity report card grades for children and youth: results and analysis from 49 countries. $J$ Phys Act Health. 2018;15(Supp1 2):S251-S273.

5. Guthold R, Stevens GA, Riley LM, Bull FC. Global trends in insufficient physical activity among adolescents: a pooled analysis of 298 population-based surveys with 1.6 million participants. Lancet Child Adolesc Health. 2020;(4):23-35.

6. World Health Organization. Global Status Report on Non-communicable Diseases. Available at: https://www.who.int/chp/ncd_global_status_report/en/. Accessed May 12, 2017.

7. The Hong Kong Special Administrative Region of the People's Republic of China. Towards 2025: Strategy and Action Plan to Prevent and Control Non-communicable Diseases in Hong Kong, Summary Report. Available at: https://www.chp.gov.hk/files/pdf/saptowards2025 summaryreport en.pdf. Accessed November 19, 2018.

8. Metzler MW, McKenzie TL, Van der Mars H, Shannon L, Barrett-Williams, Ellis R. Health optimizing physical education (HOPE): a new curriculum for school programs - part 1 : establishing the need and describing the model. JPERD. 2013;84(4):41-47. 
9. Sallis JF, McKenzie TL, Beets MW, Beighie A, Erwin H, Lee S. Physical education's role in public health: steps forward and backward over 20 years and HOPE for the future. Res $Q$ Exerc Sport. 2012;83(2):125-135.

10. Centers for Disease Control and Prevention. The Association between School-Based Physical Activity, Including Physical Education, and Academic Performance. Available at: https://www.cdc.gov/healthyyouth/health_and academics/pdf/pa-pe_paper.pdf. Accessed November 25, 2019.

11. Association for Physical Education (AfPE), Health Position Paper. Available at: http://www.afpe.org.uk/physical-education/wpcontent/uploads/afPE_Health_Position_Paper___January_2013.pdf. Accessed November $25,2019$.

12. World Health Organization. Physical Inactivity: A Global Public Health Problem. Available at: https://www.who.int/ncds/prevention/physical-activity/inactivity-globalhealth-problem/en/. Accessed May 12, 2017.

13. United Nations Educational, Scientific and Cultural Organization. Quality Physical Education: Guidelines for Policy-Makers. Available at: https://en.unesco.org/inclusivepolicylab/sites/default/files/learning/document/2017/1/23110 1E.pdf. Accessed July 25, 2017.

14. Gordon-Larsen P, Nelson MC, Popkin BM. Longitudinal physical activity and sedentary behavior trends: adolescence to adulthood. Am J Prev Med. 2004;27(4):277-283.

15. Telama R. Tracking of physical activity from childhood to adulthood: a review. Obesity Facts. 2009;2:187-195.

16. Telama R, Yang X, Laakso L, Viikari J. Physical activity in childhood and adolescence as predictor of physical activity in young adulthood. Am J Prev Med. 1997;13:317-323.

17. Hollis JL, Williams AJ, Sutherland R, Campbell E, Nathan N, Wolfenden L, et al. A systematic review and meta-analysis of moderate-to-vigorous physical activity levels in 
elementary school physical education lessons. Prev Med. 2015;86:34-54.

18. Lonsdale C, Rosenkranz RR, Peralta LR, Bennie A, Fahey P, Lubans DR. A systematic review and meta-analysis of interventions designed to increase moderate-to-vigorous physical activity in school physical education lessons. Prev Med. 2013;56(2):152-161.

19. Deng WH, Fredriksen Per M. Objectively assessed moderate-to-vigorous physical activity levels among primary school children in Norway: the health oriented pedagogical project (HOPP). Scand J Public Health. 2018;46 (Suppl 21):S38-S47.

20. Farooq A, Martin A, Janssen X, Wilson MG, Gibson AM, Hughes A, et al. Longitudinal changes in moderate-to-vigorous-intensity physical activity in children and adolescents: a systematic review and meta-analysis. Obesity Reviews. 2020;21:e12953. Available at: https://doi.org/10.1111/obr.12953. Accessed June 12, 2020.

21. Craig P, Dieppe P, Macintyre S, Michie S, Nazareth I, Petticrew M. Developing and evaluating complex interventions: the new medical research council guidance. $B M J$. 2008;337:a1655. Available at: https://www.bmj.com/content/337/bmj.a1655. Accessed September 11, 2020.

22. Kokkonen J, Yli-Piipari S, Kokkonen M, Quay J. Effectiveness of a creative physical education intervention on elementary school students' leisure-time physical activity motivation and overall physical activity in Finland. Eur Phys Educ Rev. 2019;25(3):796815.

23. Wan X, Wang W, Liu J, Tong T. Estimating the sample mean and standard deviation from the sample size, median, range and/or interquartile range. BMC Med. 2014;14:135.

24. Higgins JPT, Green S. Cochrane Handbook for Systematic Reviews of Interventions Version 5.1.0. The Cochrane Collaboration. Available at: https://training.cochrane.org/cochrane-handbook-systematic-reviews-interventions. Accessed Jan 15, 2020. 
25. The Joanna Briggs Institute Critical Appraisal tools for use in JBI Systematic Reviews Checklist for Quasi-Experimental Studies (non-Randomized experimental studies) Available at: https://joannabriggs.org/sites/default/files/2019-05/JBI QuasiExperimental_Appraisal Tool2017 0.pdf. Accessed Jan 15, 2020.

26. The Joanna Briggs Institute Critical Appraisal tools for use in JBI Systematic Reviews Checklist for Randomized Controlled Trials. Available at: https://joannabriggs.org/sites/default/files/2019-05/JBI_RCTs_Appraisal_tool2017_0.pdf Accessed Jan 15, 2020.

27. Moher D, Liberati A, Tetzlaff J, Altman DG, Group P. Preferred reporting items for systematic reviews and meta-analyses: the PRISMA statement. PLoS Med. 2009;6(7):e 1000097. Available at: https://journals.plos.org/plosmedicine/article?id=10.1371/journal.pmed.1000097. Accessed March 26, 2020.

28. Boulley GE, Tessier D, Ntoumanis N, Sarrazin P. Need-supportive professional development in elementary school physical education: effects of a cluster-randomized control trial on teachers' motivating style and student physical activity. Sport Exerc Perform Psychol. 2018;7(2):218-234.

29. Fairclough SJ, McGrane B, Sanders G, Taylor S, Owen M, Curry W. A non-equivalent group pilot trial of a school-based physical activity and fitness intervention for 10-11 year old English children: born to move. BMC Public Health. 2016;16:861.

30. Powell E, Woodfield LA, Nevill AM. Increasing physical activity levels in primary school physical education: the SHARP principles model. Prev Med Reports. 2016;3:7-13.

31. Smith L, Harvey S, Savory L, Fairclough S, Kozub S, Kerr C. Physical activity levels and motivational responses of boys and girls: a comparison of direct instruction and tactical games models of games teaching in physical education. Eur Phys Educ Rev. 2015;21(1), 93-113. 
32. Telford RM, Olive LS, Cochrane T, Davey R, Telford RD. Outcomes of a four-year specialist-taught physical education program on physical activity: a cluster randomized controlled trial, the LOOK study. Int J Behav Nutr Phys Act. 2016;13:64.

33. Powell E, Woodfield LA, Powell AJ, Nevill AM. Assessing the wider implementation of the SHARP principles: increasing physical activity in primary physical education. Sports. 2020;8(1):6.

34. Eloise E, Heather E, Tina H, Brent H. Comprehensive school physical activity programs: helping all students achieve 60 minutes of physical activity each day. JPERD. 2013;84(9): 9-15.

35. Eather N, Morgan PJ, Lubans DR. Improving the fitness and physical activity levels of primary school children: results of the fit-4-fun group randomized control trial. Prev Med. 2013;56(1):12-19.

36. Ryan R, Deci E. Self-determination theory and the facilitation of intrinsic motivation, social development and wellbeing. Am Psychol. 2000;55(1):68-78.

37. Jones RJA, Marshall S, Peters DM. Can we play a game now? The intrinsic value of TGfU. Eur J Phys Health Educ. 2010;4(2):57-63.

38. McClain JJ, Abraham TL, Brusseau Jr TA, Tudor-Locke C. Epoch length and accelerometer outputs in children: comparison to direct observation. Med Sci Sports Exerc. 2008;40:2080-2087.

39. Martin A, Boyle J, Corlett F, Reilly JJ, Kelly P. Contribution of walking to school to individual and population moderate-vigorous intensity physical activity: systematic review and meta-analysis. Pediatr Exerc Sci. 2016;28:353-363.

40. Grasten A, Yli-Piipari S. The patterns of moderate to vigorous physical activity and physical education enjoyment through a 2-year school-based program J Sch Health. 2019;89(2):88-98.

41. Johnston G, Martin A, McIntosh S, Reilly JJ. Contribution of school recess to daily 
physical activity: systematic review and evidence appraisal. Health Behav Policy Rev. 2016;3(6):581-589.

42. Johnstone A, Hughes AR, Martin A, Reilly JJ. Utilizing active play interventions to promote physical activity and improve fundamental movement skills in children: a systematic review and meta-analysis. BMC Public Health. 2018;18:789.

43. McKenzie TL, Sallis JF, Nader PR. SOFIT: system for observing fitness instruction time. $J$ Teach Phys Educ.1992;11(2):195-205.

44. Camacho-Minano MJ, LaVoi NM, Barr-Anderson DJ. Intervention to promote physical activity among young and adolescent girls: a systematic review. Health Educ Res. 2011;26 (6):1025-1048. 
Appendix A

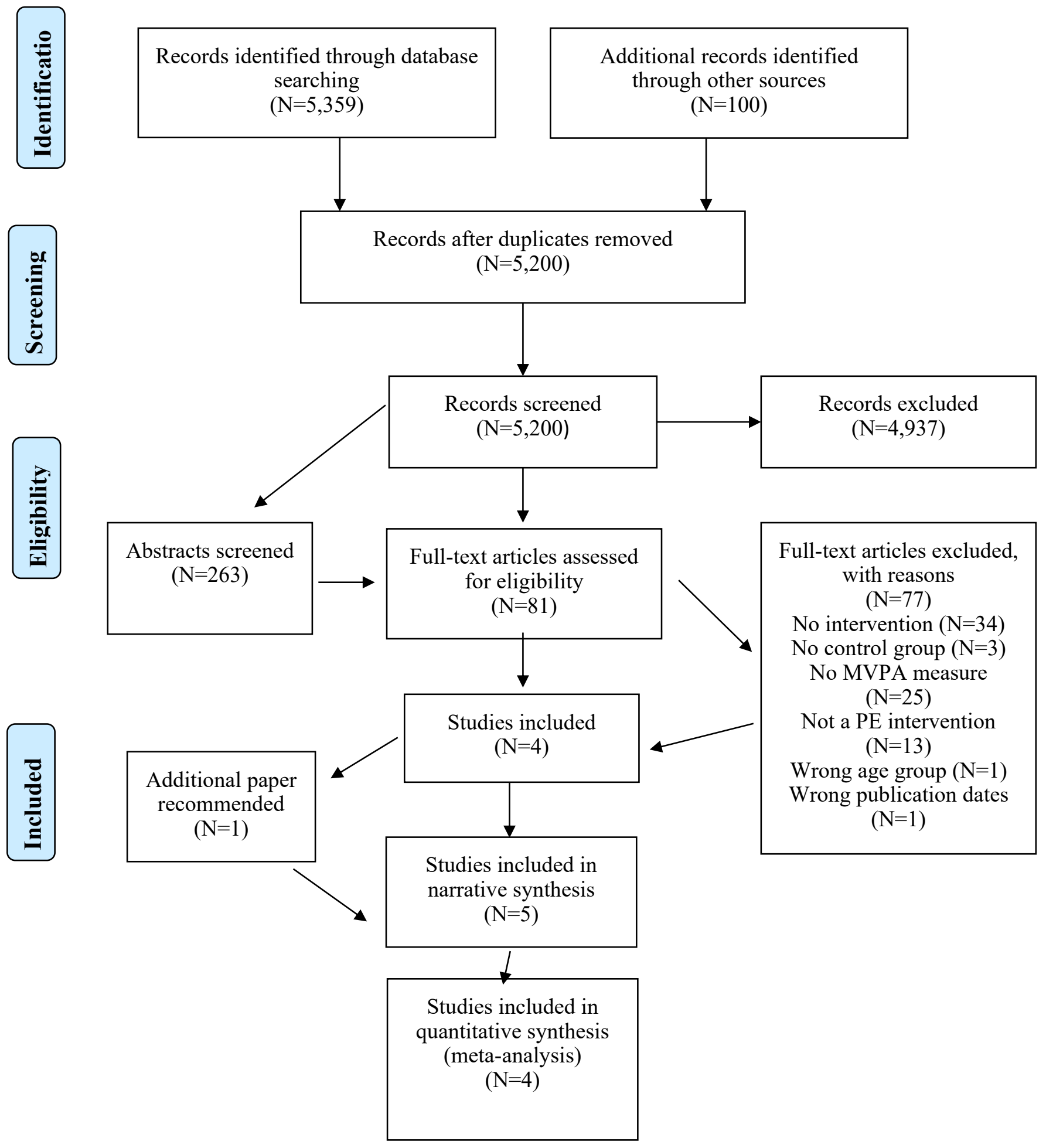

Fig 1. Flow Diagram of Number of Articles Retrieved during the Literature Search and Study Selection 
Table 1 Search Strategy in Scopus

\section{Search Strategy}

"physical activit*،

"moderate-to-vigorous-physical activity"

"active learning"

movement

exercise

fitness

"motor activity"

"activity level*"

1 or 2 or 3 or 4 or 5 or 6 or 7 or 8

"physical education"

PE or P.E.

10 or 11

Intervention

experiment

training

compar*

Contrast*

Condition

13 or 14 or 15 or 16 or 17 or 18

Student* or pupil

Learner

child* or adolesc*

school*

20 or 21 or 22 or 23

9 and 12 and 19 and 24

limit 25 to English language

limit 26 to $y r .=$ "2010 to current"

The source type was restricted to peer-reviewed journals. Subjects like aging, paediatrics, disability, cancer, employment, religion, older people, college students or surgery were excluded. 
Table 2 - Overview of Study Design and Sample Characteristics

Appendix C

\begin{tabular}{|c|c|c|c|c|c|c|c|}
\hline Citation & $\begin{array}{l}\text { Study Design } \\
\text { (Country) }\end{array}$ & $\begin{array}{l}\text { Sample Size } \\
\text { Intervention } \\
\text { /Control }\end{array}$ & $\begin{array}{l}\text { Age of } \\
\text { Students at } \\
\text { Baseline }\end{array}$ & $\begin{array}{l}\text { Intervention } \\
\text { Duration }\end{array}$ & $\begin{array}{l}\text { MVPA Outcome } \\
\text { Measurement }\end{array}$ & Intervention Details & $\begin{array}{l}\text { Comparison or } \\
\text { Control Group }\end{array}$ \\
\hline $\begin{array}{l}\text { Boulley et } \\
\text { al. } 2018^{28}\end{array}$ & $\begin{array}{l}\text { Cluster RCT } \\
\text { (France) }\end{array}$ & $\begin{array}{l}293 \text { students } \\
\text { (15 teachers from } 13 \\
\text { elementary schools) } \\
\text { Eight teachers in } \\
\text { control group } \\
\text { Seven teachers in } \\
\text { intervention group }\end{array}$ & $\begin{array}{l}\text { Mean age }= \\
8.3 \\
\left(1^{\text {st }} \text { to } 5^{\text {th }}\right. \\
\text { grade })\end{array}$ & $\begin{array}{l}\text { A school } \\
\text { year } \\
\text { From Oct to } \\
\text { June }\end{array}$ & $\begin{array}{l}\text { Accelerometer } \\
\text { (SenseWear }{ }^{\circledR} \text { pro2 } \\
\text { Armband } 6.1 \\
\text { BodyMedia, INC., } \\
\text { PA, USA) }\end{array}$ & $\begin{array}{l}\text { A teacher professional } \\
\text { development program } \\
\text { grounded in self- } \\
\text { determination theory to } \\
\text { increase generalist } \\
\text { teachers' need-supportive } \\
\text { motivating style and } \\
\text { consequently their students' } \\
\text { physical activity during PE } \\
\text { lessons }\end{array}$ & $\begin{array}{l}\text { Standard PE } \\
\text { (by generalist } \\
\text { teachers) }\end{array}$ \\
\hline $\begin{array}{l}\text { Fairclough } \\
\text { et al. } 2016^{29}\end{array}$ & $\begin{array}{l}\text { Quasi- } \\
\text { Experimental } \\
\text { (UK) }\end{array}$ & $\begin{array}{l}139 \text { students } \\
\text { Two control schools } \\
\text { Two intervention } \\
\text { schools }\end{array}$ & $\begin{array}{l}\text { 10-11 years } \\
\text { (grade 6) }\end{array}$ & 6 weeks & $\begin{array}{l}\text { Accelerometers } \\
\text { (Actigraph GT9X, } \\
\text { ActiGraph LLC, } \\
\text { FL) }\end{array}$ & $\begin{array}{l}\text { Twice-weekly 'Born to } \\
\text { Move' (BTM) physical } \\
\text { activity and fitness } \\
\text { intervention alongside a } \\
\text { regular PE lesson. } \\
\text { BTM element delivered by } \\
\text { an expert instructor and } \\
\text { regular PE lessons } \\
\text { delivered by generalist } \\
\text { teachers } \\
\text { (3 lessons per week) for } \\
\text { intervention group }\end{array}$ & $\begin{array}{l}\text { Children in the } 2 \\
\text { comparison } \\
\text { schools received } \\
\text { their regular twice } \\
\text { weekly PE } \\
\text { lessons } \\
\text { (by generalist } \\
\text { teachers) }\end{array}$ \\
\hline
\end{tabular}




\begin{tabular}{|c|c|c|c|c|c|c|c|}
\hline $\begin{array}{l}\text { Powell et al. } \\
2016^{30}\end{array}$ & $\begin{array}{l}\text { Quasi- } \\
\text { Experimental } \\
\text { (UK) }\end{array}$ & $\begin{array}{l}95 \text { students (with } 111 \\
\text { students at based line) } \\
\text { One control school and } \\
\text { One intervention } \\
\text { school }\end{array}$ & $\begin{array}{l}7-9 \text { years } \\
\text { (grade } 3-4)\end{array}$ & I year & SOFIT & $\begin{array}{l}\text { Intervention based on self- } \\
\text { determination theory and } \\
\text { the socio-ecological model. } \\
\text { Used the SHARP Principles } \\
\text { Model. } \\
\text { Delivered by individual } \\
\text { generalist teacher, on-going } \\
\text { supported by the PE } \\
\text { coordinator and the Head } \\
\text { Teacher who developed and } \\
\text { adapted a PE and PA policy } \\
\text { and curriculum map }\end{array}$ & $\begin{array}{l}\text { Standard PE } \\
\text { (by generalist } \\
\text { teachers) }\end{array}$ \\
\hline $\begin{array}{l}\text { Smith et al. } \\
2015^{31}\end{array}$ & $\begin{array}{l}\text { Quasi- } \\
\text { Experimental } \\
\text { (UK) }\end{array}$ & $\begin{array}{l}72 \text { students } \\
\text { (42 boys, } 30 \text { girls) } \\
\text { Two schools } \\
\text { (both intervention } \\
\text { group and control } \\
\text { group in the same } \\
\text { school) }\end{array}$ & $11-12$ years & 12 weeks & SOFIT & $\begin{array}{l}\text { Tactical Games Model } \\
\text { (TGM) and used Teaching } \\
\text { Games for Understanding } \\
\text { Approach } \\
\text { Delivered by physical } \\
\text { education specialists who } \\
\text { had experience of the } \\
\text { concepts surrounding TGM } \\
\text { and had attended a } \\
\text { University based training } \\
\text { course focused on TGM }\end{array}$ & $\begin{array}{l}\text { Standard PE } \\
\text { (by physical } \\
\text { education } \\
\text { specialists ) }\end{array}$ \\
\hline $\begin{array}{l}\text { Telford et al. } \\
2016^{32}\end{array}$ & $\begin{array}{l}\text { Cluster RCT } \\
\text { (Australia) }\end{array}$ & $\begin{array}{l}13 \text { Intervention } \\
\text { schools ( } 457 \text { students) } \\
16 \text { Control schools } \\
\text { (396 students) }\end{array}$ & $\begin{array}{l}8 \text { years (at } \\
\text { based line) to } \\
\text { age } 12 \text { years }\end{array}$ & 4 years & $\begin{array}{l}\text { System for } \\
\text { Observing Fitness } \\
\text { Instruction Time } \\
\text { (SOFIT) }\end{array}$ & $\begin{array}{l}2 \text { PE lessons per week from } \\
\text { specialist-trained PE } \\
\text { teachers } \\
(2 \times 45 \text { mins }), 90 \text { mins per } \\
\text { week and the rest } 60 \text { mins } \\
\text { was conducted by the } \\
\text { generalist teachers to meet } \\
\text { the weekly } \\
\text { recommendation } 150 \text { mins }\end{array}$ & $\begin{array}{l}\text { Standard PE, } 2 \text { PE } \\
\text { lessons per week } \\
\text { (by generalist } \\
\text { teachers) }\end{array}$ \\
\hline
\end{tabular}




\section{Appendix D}

Table 3 - Joanna Briggs Institute Critical Appraisal Checklist for Quasi-Experimental Studies (Non-Randomized Experimental Studies)

\begin{tabular}{|c|c|c|c|c|c|c|c|c|c|}
\hline Study & $\begin{array}{l}1 . \\
\text { Clear } \\
\text { Dependen } \\
\mathrm{t} \text { and } \\
\text { Independe } \\
\mathrm{nt} \\
\text { Variables } \\
?\end{array}$ & $\begin{array}{l}2 . \\
\text { Participants } \\
\text { Included in } \\
\text { Comparisons } \\
\text { Similar? }\end{array}$ & $\begin{array}{l}3 . \\
\text { Participants } \\
\text { Included in } \\
\text { Comparisons } \\
\text { Receiving } \\
\text { Similar } \\
\text { Treatment/Care? }\end{array}$ & $\begin{array}{l}4 . \\
\text { A } \\
\text { Control/Com } \\
\text { parison } \\
\text { Group? }\end{array}$ & $\begin{array}{l}5 . \\
\text { Multiple } \\
\text { Measurement } \\
\text { s of the } \\
\text { Outcome } \\
\text { both Pre and } \\
\text { Post the } \\
\text { Intervention? }\end{array}$ & $\begin{array}{l}6 . \\
\text { Follow up } \\
\text { Complete? }\end{array}$ & $\begin{array}{l}7 . \\
\text { Outcomes } \\
\text { Measured } \\
\text { in the Same } \\
\text { Way? }\end{array}$ & $\begin{array}{l}8 . \\
\text { Experimental } \\
\text { Studies } \\
\text { Outcomes } \\
\text { Measured in a } \\
\text { Reliable way? }\end{array}$ & $\begin{array}{l}9 . \\
\text { Appropriate } \\
\text { Statistical } \\
\text { Analysis? }\end{array}$ \\
\hline $\begin{array}{l}\text { Fairclough } \\
\text { et al. } 2016\end{array}$ & Yes & Yes & $\begin{array}{c}\text { No } \\
\text { Control group } \\
\text { received less PE }\end{array}$ & Yes & Yes & Yes & Yes & Yes & $\begin{array}{c}\text { Partial; } \\
\text { Power limited } \\
\text { as this was a } \\
\text { pilot study }\end{array}$ \\
\hline $\begin{array}{l}\text { Powell et } \\
\text { al. } 2016\end{array}$ & Yes & Yes & Yes & Yes & $\begin{array}{l}\text { Unclear } \\
\text { SOFIT }\end{array}$ & $\begin{array}{c}\text { Yes } \\
4 \text { weeks } \\
\text { post- } \\
\text { intervention } \\
\text { using SOFIT }\end{array}$ & Yes & Yes & $\begin{array}{c}\text { Partial; } \\
\text { No mention of } \\
\text { power and } \\
\text { clustering }\end{array}$ \\
\hline $\begin{array}{l}\text { Smith et al. } \\
2015\end{array}$ & Yes & Yes & Yes & Yes & No & Partial & Yes & $\begin{array}{c}\text { Partial } \\
\text { SOFIT and } \\
\text { accelerometers }\end{array}$ & $\begin{array}{c}\text { Partial; } \\
\text { No mention of } \\
\text { power and } \\
\text { clustering }\end{array}$ \\
\hline
\end{tabular}


Appendix E

Table 4 - Joanna Briggs Institute Critical Appraisal Checklist for RCT

\begin{tabular}{|c|c|c|c|c|c|c|c|c|c|c|c|c|c|}
\hline Study & $\begin{array}{l}1 . \\
\text { True } \\
\text { Rand } \\
\text { omiz } \\
\text { ation } \\
\text { Used } \\
?\end{array}$ & $\begin{array}{l}2 . \\
\text { Allocat- } \\
\text { ion to } \\
\text { Groups } \\
\text { Conceale } \\
\text { d? }\end{array}$ & $\begin{array}{l}3 . \\
\text { Groups } \\
\text { Similar } \\
\text { at the } \\
\text { Baseline } \\
?\end{array}$ & $\begin{array}{l}4 . \\
\text { Particip } \\
\text { ants } \\
\text { Blinded } \\
?\end{array}$ & $\begin{array}{l}5 . \\
\text { Were } \\
\text { those } \\
\text { Deliverin } \\
\mathrm{g} \\
\text { Treatment } \\
\text { Blinded? }\end{array}$ & $\begin{array}{l}6 . \\
\text { Outcom } \\
\text { es } \\
\text { Assess- } \\
\text { ors } \\
\text { Blinded } \\
?\end{array}$ & $\begin{array}{l}7 . \\
\text { Groups } \\
\text { Treated } \\
\text { Identically } \\
\text { other than } \\
\text { Intervene- } \\
\text { tion? }\end{array}$ & $\begin{array}{l}8 . \\
\text { Follow } \\
\text { Up Comp } \\
\text { lete? }\end{array}$ & $\begin{array}{l}9 . \\
\text { Particip } \\
\text { ants } \\
\text { Analyse } \\
\text { d in } \\
\text { Allocate } \\
\text { ed } \\
\text { Groups? }\end{array}$ & $\begin{array}{l}10 . \\
\text { Outcom } \\
\text { es } \\
\text { Measure } \\
\text { ed in the } \\
\text { Same } \\
\text { Way? }\end{array}$ & $\begin{array}{l}11 \\
\text { Outcomes } \\
\text { Measured } \\
\text { Reliably? }\end{array}$ & $\begin{array}{l}12 . \\
\text { Appropr } \\
\text { iate } \\
\text { Statistic } \\
\text { al } \\
\text { Analysis } \\
?\end{array}$ & $\begin{array}{l}13 . \\
\text { Trial } \\
\text { Design } \\
\text { Appro } \\
\text { priate? }\end{array}$ \\
\hline $\begin{array}{l}\text { Boulley et } \\
\text { al. } 2017\end{array}$ & Yes & Yes & Yes & Partial & NA & Unclear & $\begin{array}{c}\text { No } \\
\text { Teachers in } \\
\text { the control } \\
\text { groups had } \\
\text { no TPD }\end{array}$ & Partial & Yes & Yes & Yes & Yes & Yes \\
\hline $\begin{array}{l}\text { Telford et } \\
\text { al. } 2016\end{array}$ & Yes & Unclear & Yes & No & NA & No & $\begin{array}{c}\text { No } \\
\text { Standard } \\
\text { PE } \\
\text { control } \\
\text { group less } \\
\text { PE lesson }\end{array}$ & Yes & Yes & Yes & Yes & Partial & Yes \\
\hline
\end{tabular}

